\title{
The Effect of Profitability, Company and Board of Commissioners' Size on Zakat Expenditure in Islamic Bank
}

\author{
Nur Kholidah $^{1 *}$, Muhammad Arifiyanto ${ }^{2}$, Miftahur Rahman Hakim ${ }^{1}$ \\ ${ }^{1}$ Department of Islamic Economic, University Muhammadiyah Pekajangan Pekalongan, Indonesia \\ ${ }^{2}$ Department of Management, University Muhammadiyah Pekajangan Pekalongan, Indonesia \\ *Corresponding author. Email: nur.kholidah92@gmail.com
}

\begin{abstract}
Islamic banks as financial institutions engaged in Sharia finance services have been supposed to issue zakat following Islamic rules and legislation so that the purpose of benefits and blessings can be achieved.

However, the awareness to pay Zakat company can be said still quite low in Indonesia. This research aims to analyse the influence of profitability, size of the company, and the size of the Board of Commissioners to the issuance of zakat of Sharia public Bank in Indonesia in 2010-2018. The sampling technique used was purposive sampling and the analysis technique used was multiple linear regression. The results of this study showed that simultaneously, all independent variables in this study had a significant influence on the issuance of zakat in sharia Bank with a significance value of 0.005. Partial test results show that the size of the Board of Commissioners does not affect zakat expenditure. While the profitability and size of companies influence positive and significant to the expenditure of zakat. We issue Islamic banks that issue Islamic principles and do not need to worry about zakat issuance because they do not need to increase but increase wealth.
\end{abstract}

Keywords: profitability, company, zakat expenditure, Islamic bank

\section{INTRODUCTION}

Islam as a religion that has the most significant adherents in Indonesia, has provided solutions to the problem of poverty. The solution offered to alleviate poverty is through zakat. One of the high potentials of zakat in our country, but has not been widely socialized and evenly distributed and has not been maximally collected is corporate zakat.

Obligations of corporate zakat in Article 1 of Law No. 23/2011 concerning Management of Zakat, it is stated that a muzaki is a Muslim or a business entity that is obliged to pay zakat. Thus, both fiqh and positive legal rules in this country, companies that have fulfilled the requirements must pay their zakat, in addition to the zakat of the directors, commissioners, and their employees. In this case, the zakat company is one of the charity funds to be collected if it is over the threshold ratio and beyond one haul as instructed in the Qur'an, As-Sunna, and the ijma 'ulama [1].

Juridically, the Law has become the basis for Islamic banking institutions to pay zakat. Sharia Commercial Bank applies a development strategy by implementing the basic principles of Islamic economics. So, the goal of Islamic banks is not only profit-oriented but also oriented to Falah. With the falah oriented, Islamic banks that organize shariabased businesses, are also oriented to zakat, which can be seen from how much the ability of Islamic banks to issue their zakat [2].
Although the total asset data from several Sharia Commercial Banks shows an increase every year, it is not accompanied by the growth in zakat expenditures of the Sharia Commercial Bank. Zakat data of Islamic Commercial Banks can be seen from the following figures:

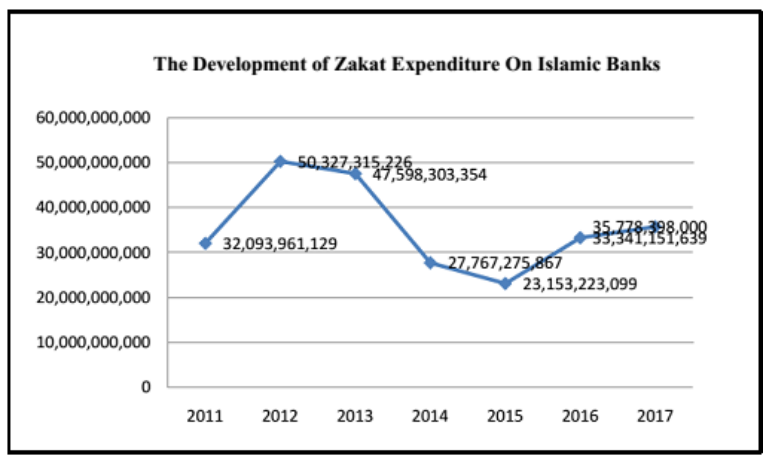

Figure 1 The development of zakat expenditure on Islamic banks

Judging from the figures above, the expenditure of Islamic bank zakat unlike the total growth of Islamic bank assets which showed an increase every year. From the above table, zakat expenditure on Islamic banks decreased in 2014, but in the same year the total Islamic bank assets have increased.

On this basis, research on corporate zakat is fundamental. Until now, the management of zakat is still dominated by individual zakat [1], so the company zakat is very potential for revenue sources [3], [4]. Another factor influencing zakat payment is the board of commissioners. The size of the board of commissioners is the number of commissioners in a company. In relation to the issuance of zakat companies, namely because the board of commissioners has 
the authority to give advice and influence the directors in making decisions on payment of zakat in the corporate environment [5].

Some studies related to this research are research conducted by Yusnita et al., [6] Herwanti [7], and Muhammad [8], the results of which states that profitability has a significant effect on zakat both simultaneously and partially. In contrast to research conducted by Samad et al. [9], Utari \& Ninglasari [10], and Afandi [11], which stated that the profitability variable of Islamic banks does not always have an effect on corporate zakat spending by Islamic banks. Even though the company gets a small profit, it is still obliged to issue zakat.

Research on company size was examined by Utari et al., [10] and Samad et al., [9] whose results showed that company size affected both simultaneous and partial zakat expenditure. However, contrary to the results of Afandi's research [11], the result is that the size of the company does not affect zakat expenditure.

One of the motivations behind this research is the inconsistency of research results regarding profitability, company size, and the size of the board of commissioners regarding the sharia zakat financial institution's spending ability. The purpose of this study was to determine the effect of profitability, company size, and board of commissioner size on company zakat expenditure. So, the implication is that the company can consciously be oriented to zakat, because the orientation to zakat is oriented to the overall performance of the company because of the more significant the expenditure of zakat, the more the company's performance increases.

\section{METHOD}

The research method used is the causality method using a quantitative approach. The data used in this study is secondary data. Also, data collection techniques in this study are documentation studies obtained from the BUS annual financial reports, as well as monthly BUS publications reports on the OJK website (www.ojk.go.id). Data collection was also carried out through the literature study.

The population in this study were all Islamic commercial banks in Indonesia in the 2011-2015 period, amounting to 14 banks. This study used a purposive sampling method with criteria: (1) Sharia-based bank in Indonesia; (2) such banks should be established before 2011; (3) Islamic commercial banks which publish zakat in the 2011-2018 financial statements. Based on the above criteria, the sample in this study was 5 Islamic commercial banks in Indonesia, namely Syariah Mandiri Bank, Mega Syariah Bank, Muamalat Bank, BNI Syariah, and BRI Syariah.

The variables in this study are divided into two, namely the dependent variable and the independent variable. The dependent variable in this study is the company zakat, while the independent variables in this study are profitability ratios, which are proxied by Return on Assets (ROA), company size, and board of commissioner size.

Table 1 Definition of variable operations

\begin{tabular}{|c|c|c|c|}
\hline No & Variable & Operational definition & Indicator \\
\hline 1 & Zakat expenditure (Y) & $\begin{array}{l}\text { Zakat is the issuance of property specifically to people } \\
\text { who are entitled to receive it under certain conditions } \\
{[12] \text {. }}\end{array}$ & Zakat $=$ profit $\times 2,5 \%$ \\
\hline 2 & Profitability (X1) & $\begin{array}{l}\text { Profitability ratios are ratios used to measure the } \\
\text { effectiveness of banks in making profits [13] }\end{array}$ & $\mathrm{ROA}=\frac{\text { profit after tax }}{\text { Total assets }} \times 100 \%$ \\
\hline 3 & Company Size (X2) & $\begin{array}{l}\text { Company size is the size of the company is a measure of } \\
\text { the size of assets owned by the company. }\end{array}$ & $\begin{array}{l}\text { Asset size is used to measure the size of } \\
\text { the company, the size of the asset is } \\
\text { measured as a logarithm of total } \\
\text { assets[14]. }\end{array}$ \\
\hline 4 & $\begin{array}{lr}\text { Board } & \text { of } \\
\text { Commissioners' } & \text { size } \\
\text { (X3) }\end{array}$ & $\begin{array}{l}\text { The size of the board of commissioners is the number of } \\
\text { boards that exist or work in a company [5] }\end{array}$ & Number of commissioners \\
\hline
\end{tabular}

Hypotheses on this study are:

H1: Profitability affects zakat expenditure on sharia bank in Indonesia.

$\mathrm{H} 2$ : The size of the company affects zakat spending on sharia banks in Indonesia.

H3: The size of the board of directors affects the expenditure of zakat on sharia banks in Indonesia.

The data is analysed using the Statistical Package for Social Science (SPSS) version 23.0. Before carrying out multiple regression analyses, first testing the classical assumptions are the multicollinearity test, autocorrelation test, heteroscedasticity test, and normality test. In this study, the multiple regression model developed is as follows:

$$
\begin{array}{ll}
\mathrm{Y} & =\mathrm{a}+\beta 1 \mathrm{X} 1+\beta 2 \mathrm{X} 2+\beta 3 \mathrm{X} 3+e \\
\mathrm{Y} & =\text { Zakat } \\
\mathrm{a} & =\text { a constant } \\
\mathrm{b} 1, \mathrm{~b} 2, \mathrm{~b} 3 & =\text { Regression Coefficient } \\
\mathrm{X} 1 & =\text { Profitability } \\
\mathrm{X} 2 & =\text { Company Size } \\
\mathrm{X} 3 & =\text { Board of Commissioners' size }
\end{array}
$$




\section{RESULTS AND DISCUSSION}

\subsection{Testing and Data Analysis Results}

To test the hypothesis previously proposed that profitability, company size, and board of commissioners influence the expenditure of zakat on BUS in Indonesia, then the following results of the analysis of research data with SPSS 23.0 software.

Normality test results show a probability value of 0.200 , and this value is more significant than 0.05 . This means that the data is normally distributed. Heteroscedasticity test results show the probability value for X1 (profitability), X2 (company size), and X3 (board of commissioners) of 0.095 ; 0.057 and 0.403 . These values are more significant than 0.05 , which means that there is no heteroscedasticity problem. The autocorrelation test results show a probability value of 0.873 , and this value is more significant than 0.05 so that no autocorrelation occurs. Multicollinearity test results show the tolerance value for X1 (profitability), X2 (company size), and X3 (board of commissioners) of 0.898; 0.618 and 0.579 . These values are more significant than 0.10 , which means that there is no multicollinearity problem.

Adjust R Square value of 0.295 , which means that the zakat variable can be explained by independent variables by $29.5 \%$, while the remaining $70.5 \%$ is explained by other factors not examined. Furthermore, based on the $F$ statistical test, it is known that the calculated $F$ value is 9,013 , with a significance value of 0.005 . This means that the significance value is less than 0.05 . So it can be concluded that simultaneously, the independent variable has a significant influence on the dependent variable.

Based on the regression results show that the significance value for the variable ROA is 0.00 , which means it is smaller than 0.05 , so it can be concluded that ROA has a positive effect on zakat. For company size variables that are proxied with total assets, a significance value of 0.001 is obtained, which means that it is smaller than 0.05 , so it can be concluded that the size of the company that is proxied by total assets affects the zakat expenditure. For the size of the board of commissioners obtained a significance value of 0.144 , which means higher than 0.05 , so it was concluded that the size of the board of commissioners did not affect zakat expenditure. The regression equation model is as follows:

Zakat $=4,208+0,120$ ROA +0.572 Company Size +0.052

Board of Commissioners $+e$

a. From the multiple linear regression equation can be described as follows:

b. The constant value is 4,208 with a positive value. This shows that if the variable profitability, company size, and board size are equal to zero, then zakat is 4,208.

c. Profitability variable regression coefficient $(\beta 1)$ of 0.120 with a positive value. This shows that the higher the profitability, the higher the zakat paid.

d. Firm size variable regression coefficient $(\beta 2)$ of 0.6572 with a positive value. This shows that the bigger the company, the greater the zakat issued.

e. Regression coefficient of commissioner size variable ( $\beta 3)$ is 0.052 with a positive value. This shows that the more the number of board of commissioners, then the zakat paid will be more in accordance with the established sharia provisions.

\subsection{Discussion of Data Analysis Results}

For the first hypothesis, based on the results obtained indicate that ROA has a positive effect on the expenditure of Islamic bank zakat. These results indicate that the higher the profitability will affect the amount of zakat that will be issued. The higher the profitability achieved by Islamic banks, the greater the ability to pay zakat. Profits greatly affect the zakat paid by Islamic banks because profits are the key concept in determining the amount of zakat that must be paid by Islamic banks. It can be said that ROA increases, it will cause a greater level of profit achieved by the bank and that if the bank's financial performance is good, the charitable funds spent will be greater. The results of this study are consistent with research conducted by Yusnita, et al. [6] the ability of zakat can be influenced by ROA, and there is a simultaneous relationship between the ability of zakat and ROA. This study also supports the results of previous studies by Herwanti et al. [7] and Muhammad [8] who used ROA as one of the independent variables explained that ROA has a positive and significant effect on the amount of zakat paid by Islamic banks. Khanifar et al. [15] argue that being socially responsible will inevitably affect the company's profitability. Zakat is very important in socio-economics by reducing poverty. In other words, anyone who practices zakat means that they are socially responsible. So, zakat is one of the important aspects that companies must consider to maintain their financial performance.

For the second hypothesis, based on the results obtained indicate that the size of the company has a positive effect on the expenditure of Islamic bank zakat. This means that Islamic banks that have many assets and are well managed can generate significant revenues so that it is directly proportional to large profits as well. The amount of zakat the bank pays is calculated from the profits obtained. The higher the profit, the zakat paid will be even greater. Large companies, in general, will be far more able to increase their profit levels because they have more resources than smaller companies. With a significant increase in assets, companies or Islamic banks tend to be freer to take any policy, including the policy of issuing zakat. The results of this study are consistent with research conducted by Utari, et al. [10], Samad, et al. [9], that the size of the company has a positive and significant influence on the company's zakat expenditure. Thus, based on the findings in this study that are associated with theoretical concepts and supported by empirical facts from previous studies, it can be concluded that the size of the company which is proxied by total assets has a positive and significant effect on the expenditure of Islamic Bank (BUS) sharia companies in Indonesia, so that the results of this study support the results of previous study. The third hypothesis, based on the results obtained, indicates that the size of the board of commissioners does not affect zakat expenditure. This shows that the increasing number of boards of commissioners is not a guarantee of the amount of zakat that will be issued. Because the more the 
[5] H. Md, A. Kasumalinda, A. Agoos, and M. Tahir, "2nd International conference on business and economic research (2nd icber 2011) proceeding factors influence company towards zakat payment: an explanatory studies," 2011.

[6] R. R. Yusnita, Y. Z. Basri, T. Mariyanti, . Z., and W. Arafah, "Analysis of Effect of Profitability, Capital, Risk Financing, the Sharia Supervisory Board and Capabilities Zakat in Islamic Perspective with Circular Approach Causastion on Islamic Banks in Indonesia," Econ. Financ. Lett., vol. 6, no. 2, pp. 149-158, 2019.

[7] M. N. F. Herwanti, Titiek; Irwan, "Disclosure Level's Effect of Islamic Social Reporting on Company's Profitability and Zakat," vol. 6, no. 2, pp. 85-98, 2017.

[8] M. Izlawanie, "Factors that Influence Business Compliance among Small and Medium," J. Muamalat Islam. Financ. Res., vol. 13, no. 1, pp. 97-110, 2016.

[9] K. A. Samad, R. Said, M. H. Kamarulzaman, and M. Mahshar, "Exploring the Zakat Payment and Firm ' s Performance of Islamic Banks in Malaysia," 6th Int. Conf. Governance, Fraud. Ethics Soc. Responsib. 2015 (iConGFESR 2015) Explor., vol. 2015, no. June, pp. 16, 2015.

[10] R. Utari, H. Monoarfa, and S. Yayu Ninglasari, "Factors Influencing Corporate Zakat Expenditure (Case Study of Islamic Banks in Indonesia Period 20152017)," KnE Soc. Sci., vol. 3, no. 13, p. 413, 2019.

[11] M. A. Afandi, "Profitability Variables and Bank Size Effects on Corporate Zakat : Evidence from Indonesia Islamic Bank,” vol. 4, no. 23, pp. 55-66, 2019.

[12] M. Sholahuddin, Lembaga Keuangan dan Ekonomi Islam. Yogyakarta: Penerbit Ombak, 2014.

[13] D. Siamat, Manajemen Lembaga Keuangan, Keempat. Jakarta: Fakultas Ekonomi Universitas Indonesia, 2005.

[14] Jogianto, Teori Portofolio dan Analisis Investass. Yogyakarta: BPFE, 2007.

[15] H. Khanifar, K. Nazari, M. Emami, and H. Soltani, "Impacts Corporate Social Responsibility Activities on Company Financial Performance,” Interdiscip. J. Contemp. Res. Bus., vol. 3, no. 9, pp. 583-592, 2013.

[4] J. Almarri and J. Meewella, "Social entrepreneurship and Islamic philanthropy," Int. J. Bus. Glob., vol. 15, no. 3, pp. 405-424, 2015. 